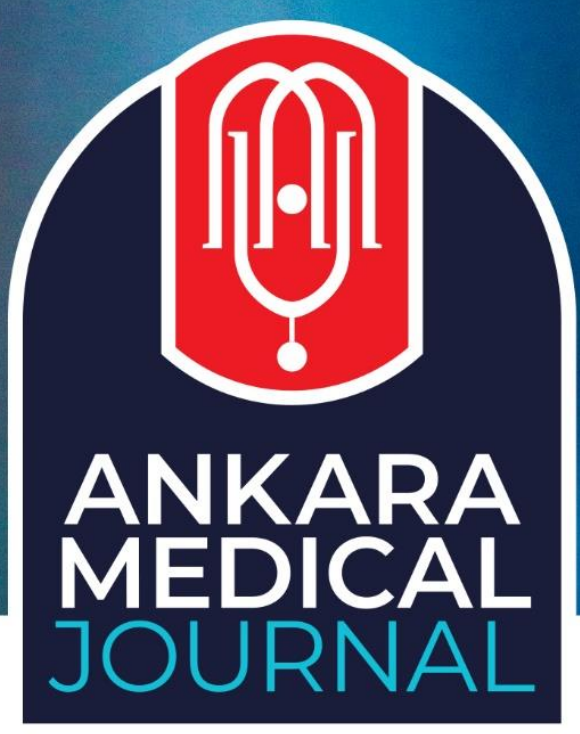

Research Article

Ankara Med J, 2021;(4):635-644 // đoi 10.5505/amj.2021.62444

\title{
A NEW BIOMARKER OF OXIDATIVE STRESS IN OBSTRUCTIVE JAUNDICE: DYNAMIC THIOL- DISULPHIDE HOMEOSTASIS
}

TIKANMA SARILIĞINDA OKSIDDATİF STRESİN YENİ BİR BIYYOLOJIKK BELİRTECİ: DİNAMIKK TIYOL-DİSÜLFİ HOMEOSTAZI

\section{Fadime Güllü Haydar1', (D) Yavuz Otal'2, (D) Gamze Avcıoğlu ${ }^{3}$ (D) Selda Kıdak Özkaya4, (D) Alp Şener ${ }^{4}$, (D) Servan Gökhan ${ }^{4}$ (i) Yunus Halil Polat ${ }^{5}$, (D) Özcan Erel 6}

1Department of General Surgery, Ankara City Hospital, Ankara 2Department of Emergency Medicine, Ankara City Hospital, Ankara

${ }^{3}$ Department of Medical Biochemistry, Karadeniz Ereğli State Hospital,Zonguldak

${ }^{4}$ Department of Emergency Medicine, Faculty of Medicine, Yildirim Beyazit University, Ankara

${ }^{5}$ Department of Gastroenterology, Ankara City Hospital, Ankara

${ }^{6}$ Department of Medical Biochemistry, Faculty of Medicine, Yildirim Beyazit University, Ankara

Yazışma Adresi / Correspondence:

Fadime Güllü Haydar (e-mail: gulluercanhaydar@gmail.com)

Geliş Tarihi (Submitted): 30.09.2021 // Kabul Tarihi (Accepted): 15.12.2021

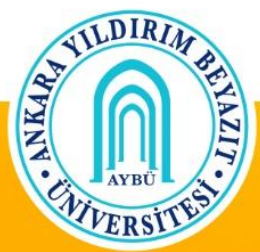




\title{
Öz
}

Amaç: Tiyol-disülfid(TDH) homeostazı birçok hastalıkta araştırılmıştır. Bu çalışmanın amacı, tıkanma sarılığı tanısı konan hastalarda dinamik tiyol-disülfid homeostazını araştırmak ve dinamik tiyol-disülfid homeostazını iskemi modifiye albümin ile karşılaştırmaktır.

Materyal ve Metot: Acil servise başvuran 69 hasta ve 77 sağlıklı gönüllüden oluşan toplam 146 katılımcı çalışmaya dahil edildi. Hastalardan başvuru anında detaylı kan örnekleri alındı. Tıkanma sarılığı tanısı konulan hastalarda, başvuru sırasında Erel ve Neselioğlu tarafından geliştirilen yepyeni bir yöntemle tiyol/disülfit düzeylerine bakıldı. Veriler bilgisayar sisteminde değerlendirildi.

Bulgular: Tıkanma sarılığı olan hastada total tiyol $(\mathrm{p}=0,025)$ ve nativ tiyol $(\mathrm{p}=0,023)$ düzeyleri kontrol grubuna göre istatistiksel olarak anlamlı derecede düşüktü. Nativ tiyol düzeyleri ile ALP $(r=-0,262, p<0,01)$, üre $(r=-0,313, p<0,01)$, total bilirubin $(r=-0,388, p)$ arasında anlamlı negatif korelasyon olduğu gözlendi. $<0,01)$, direkt bilirubin $(r=-0,351, p<0,01)$ seviyeleri. Aynı zamanda, disülfit düzeyi $(p=0,235)$ hasta grubunda kontrol grubuna göre daha düşüktü ancak istatistiksel olarak anlamlı değildi. Kontrol grubunda iskemi modifiye albümin (IMA) değerlerinin tıkanma sarılığı grubuna göre daha düşük olduğu bulundu $(p=0,03)$.

Sonuç: Tıkanma sarılığı patogenezinde total tiyol ve nativ tiyol seviyeleri azalmaktadır. Tiyol-disülfit homeostazı, tıkanma sarılığında oksidatif stresin yeni bir biyobelirteç olabilir.

Anahtar Kelimeler: Tıkanma sarılığı, tiyol-disülfid homeostazı, iskemi modifiye albümin.

\begin{abstract}
Objectives: The thiol-disulphide (TDH) homeostasis was investigated in a number of disorders. The aim of the present study is to investigate the dynamic thiol-disulphide homeostasis in patients diagnosed with obstructive jaundice and to compare the dynamic thiol-disulphide homeostasis with ischemia-modified albumin.

Materials and Methods: A total of 146 participants who were admitted to the emergency department and who consisted of 69 patients and 77 healthy volunteers were included in the study. Detailed blood samples were obtained from the patients at the time of admission. Thiol/disulphide levels were examined using a brand-new method developed by Erel and Neselioglu on the patients diagnosed with obstructive jaundice during the admission. Data were evaluated in the computer system.

Results: The levels of total thiol $(p=0.025)$ and native thiol $(p=0.023)$ were statistically significantly lower in the patient with obstructive jaundice than in the control group. It was observed that there was a significant negative correlation between the native thiol levels and the ALP $(r=-0.262, p<0.01)$, urea $(r=-0.313, p<0.01)$, total bilirubin ( $\mathrm{r}=-0.388, \mathrm{p}<0.01)$, direct bilirubin $(\mathrm{r}=-0.351, \mathrm{p}<0.01)$ levels. At the same time, the level of disulphide $(\mathrm{p}=0.235)$ was lower in the patient group than in the control group but not statistically significant. It was found that the ischemia modified albumin (IMA) values were lower in the control group than the obstructive jaundice group ( $\mathrm{p}=0.03)$.

Conclusion: Total thiol and native thiol levels decrease in obstructive jaundice pathogenesis. Thiol-disulphide homeostasis may be a new biomarker of oxidative stress in obstructive jaundice.

Keywords: Obstructive jaundice, thiol-disulphide homeostasis, ischemia modified albumin.
\end{abstract}




\section{Introduction}

Metabolic changes are seen after obstructive jaundice increases the load of oxidative stress. This load is further increased during the inflammatory process. In clinical and experimental studies, it was shown that the bacterial translocations and the disruptions in the intestinal barrier were seen together with oxidative stress. ${ }^{1,2}$ In an experimental study, it was shown that there was increased oxidative stress with the disruption of the intestinal barrier. Increased intestinal oxidative stress may play a critical role in important cellular changes of intestinal mucosa in obstructive jaundice, in addition to being a cellular damage factor. ${ }^{3-5}$

Thiol, most commonly known as mercaptans, are the compounds that contain a sulfhydryl group (-SH). ${ }^{6}$ The plasma thiol pool is mostly composed of albumin thiols and low molecular weight thiols such as cysteinyl glycine, cysteine (Cys), homocysteine, glutathione and $\gamma$-glutamylcysteine. ${ }^{7}$ The thiol-disulphide homeostasis (TDB) has vital importance. Thiol / disulphide homeostasis (TDH) plays a critical role in the detoxification process, and it was shown that the thiols have activities in antioxidant protection, signal transduction, enzymatic regulation, apoptosis and cellular signaling mechanisms. ${ }^{8,9}$ The thiol-disulphide homeostasis was investigated in a number of disorders. This homeostasis was measured unilaterally until 2014, but it is now determined bilaterally using a novel method developed by Erel and Neselioglu. ${ }^{\mathbf{1 0 , 1 1}}$ The aim of this study is to investigate the thiol-disulphide level, which may be a new indicator of oxidative stress in patients with obstructive jaundice, and its association with the other blood parameters.

\section{Materials and Methods}

Blood samples were obtained from a total of 146 participants who were admitted to the emergency department and who consisted of 69 patients and 77 healthy volunteers. For the diagnosis of obstructive jaundice; (a) the measurement of the total / direct bilirubin level rate, (b) ultrasonography of the hepatobiliary tract, (c) contrast-enhanced abdominal computed tomography (CT) for visualizing the distal region of the common bile duct, was performed on all patients.

Detailed blood samples were obtained from the patients at the time of admission. Thiol / disulphide levels were examined using a brand new method developed by Erel and Neselioglu on the venous blood samples of the patients diagnosed with obstructive jaundice during admission. In addition, biochemical data of the patient and control groups were recorded on the computer system.

Thiol-disulphide homeostasis (TDH) contains the parameters of native thiol (-SH), total thiol (-SH $+-\mathrm{SS})$, disulphide (-SS), and index1 = disulphide / native thiol percentage (-SS / -SH\%). Native thiol and total thiol levels in serum were measured by a newly developed automatic measurement method using a new clinical 
chemistry analyzer (Roche Hitachi Cobas c501 automated analyzer, Roche Diagnostics, USA). Disulphide level and disulphide / native thiol percentage (index 1) were generated from the measured values. Half of the difference between total thiol and native thiol amounts gives the amount of disulphide bond. The index parameter was calculated according to the percentages of disulphide and native thiol levels.

Measurement of the IMA (ischemia-modified albumin): Measurement of IMA levels was obtained using venous blood samples on admittance within 1 hour; specimens were stored for 30 minutes at room temperature and then centrifuged at $3500 \mathrm{rpm}$ for 5 minutes. Latter samples were transferred to Eppendorf tubes and stored at $-80^{\circ} \mathrm{C}$ until analysis. Albumin Cobalt Binding Test was used to detect the presence of IMA. This test was

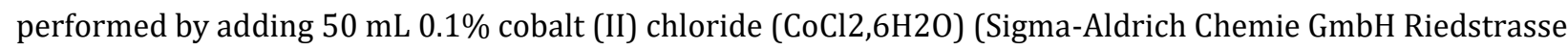
2, Steinheim, Germany) to the patient serum. After mixing, followed by 10 minutes of incubation to allow for albumin cobalt binding, $50 \mathrm{~mL} 1.5 \mathrm{mg} / \mathrm{mL}$ dithiothreitol was added. After mixing followed by 2 minutes of incubation, $1.0 \mathrm{~mL}$ of a $0.9 \%$ sodium chloride solution was added in order to reduce the binding capacity. The blank was prepared similarly with distilled water instead of dithiothreitol. The absorbance of samples was measured at $470 \mathrm{~nm}$ using a spectrophotometer. The results were expressed as absorbance units (ABSU). 12

\section{Statistical Analysis}

Data were analyzed using the SPSS Software for Windows 22.0 (SPSS Inc. Chicago. IL. USA). Normality analysis of the groups was performed with the Kolmogorov-Smirnov test. The averages of data with parametric distribution were compared with the Independent Sample t-Test. Pearson Correlation test was used in the correlation analysis of the data with the parametric distribution. The values of $\mathrm{p}<0.05$ and $\mathrm{p}<0.01$ were considered statistically significant.

\section{Results}

Blood samples were obtained from a total of 146 participants who were admitted to the emergency department and who consisted of 69 patients and 77 healthy volunteers. While the mean age of the control group was 45 (min-max: 21-64), it was found that the median age of the patient group was 58 (min-max: 19-92) (Table-1).

The medians of hematological and biochemical parameters, thiol / disulphide homeostasis parameters, IMA values in the patient and control groups, and the statistical analysis of differences between patient and control groups were given. It is seen that there is an inverse correlation between the total/direct bilirubin levels with the total thiol / native thiol levels and IMA values. There is no statistical relation with disulphide level (Table2). 
As seen in Table-3; when the comparison of the thiol/disulphide and IMA parameters in the control and obstructive jaundice groups was considered, the total thiol / native thiol and IMA levels were significantly lower, whereas the decrease in disulphide levels was not significant ( Figure-1a,b,c).

Total thiol level $(\mathrm{p}=0.025)$ and native thiol level $(\mathrm{p}=0.023)$ were lower in obstructive jaundice patients than in the control group. It was observed that there were a significant negative correlation between the native thiol levels and the ALP ( $r=-0.262, \mathrm{p}<; 0.01)$, urea ( $\mathrm{r}=-0.313, \mathrm{p}<; 0.01)$, total bilirubin $(\mathrm{r}=-0.388, \mathrm{p}<; 0.01)$, direct bilirubin ( $r=-0.351, p<; 0.01)$ levels. At the same time, the level of disulphide $(\mathrm{p}=0.235)$ was lower in the patient group than in the control group but not statistically significant. It was found that the IMA values were higher in the patient group than in the control group $(\mathrm{p}=0.03)(\mathrm{Table}-2)$.

The medians of hematological and biochemical parameters, thiol / disulphide homeostasis parameters, IMA values in the patient and control groups, and the statistical analysis of differences between patient and control groups were given. It is seen that there is an inverse correlation between the total/direct bilirubin levels with the total thiol / native thiol levels and IMA levels. There is no statistical relation with disulphide level (Table2).

Table 1. Demographic characteristics of obstructive jaundice and control groups.

\begin{tabular}{|c|c|c|}
\hline Parameters & Control group $(n=69)$ & OJ group $(n=77)$ \\
\hline Age, mean $\pm \mathrm{SD}$, range, years & $45.1 \pm 12.0,21-64$ & $72.2 \pm 14.1,24-82$ \\
\hline Gender, female/male & $32 / 37$ & $41 / 36$ \\
\hline $\mathrm{Na}$, mean $\pm \mathrm{SD}, \mathrm{mmol} / \mathrm{L}$ & $141.4 \pm 4.6$ & $136.5 \pm 5.4$ \\
\hline $\mathrm{K}$, mean $\pm \mathrm{SD}, \mathrm{mmol} / \mathrm{L}$ & $4.4 \pm 0.9$ & $4.2 \pm 0.2$ \\
\hline Glucose, mean $\pm \mathrm{SD}, \mathrm{mg} / \mathrm{dL}$ & $92.3 \pm 6.2$ & $102.2 \pm 14.8$ \\
\hline Urea, mean \pm SD, mg/dL & $29.1 \pm 10.2$ & $22.3 \pm 31.2$ \\
\hline Creatinine, mean $\pm \mathrm{SD}, \mathrm{mg} / \mathrm{dL}$ & $0.7 \pm 0.1$ & $0.8 \pm 0.4$ \\
\hline $\mathrm{AST}$, mean $\pm \mathrm{SD}, \mathrm{U} / \mathrm{L}$ & $22.2 \pm 6.7$ & $229.7 \pm 20.4$ \\
\hline $\mathrm{ALT}$, mean $\pm \mathrm{SD}, \mathrm{U} / \mathrm{L}$ & $27.5 \pm 7.3$ & $231.5 \pm 24.9$ \\
\hline GGT, mean \pm SD, U/L & $26.5 \pm 8.9$ & $396.5 \pm 52.3$ \\
\hline $\mathrm{LDH}$, mean $\pm \mathrm{SD}, \mathrm{U} / \mathrm{L}$ & $173.3 \pm 33.7$ & $511.5 \pm 138.1$ \\
\hline Albumin, mean $\pm \mathrm{SD}, \mathrm{g} / \mathrm{L}$ & $47.5 \pm 2.2$ & $40.2 \pm 6.4$ \\
\hline $\mathrm{ALP}$, mean $\pm \mathrm{SD}, \mathrm{U} / \mathrm{L}$ & $83.1 \pm 26.3$ & $202.6 \pm 79.9$ \\
\hline Amylase, mean $\pm \mathrm{SD}, \mathrm{U} / \mathrm{L}$ & $63.8 \pm 21.6$ & $87.6 \pm 29.5$ \\
\hline Lipase, mean \pm SD, U/L & $35.6 \pm 23.9$ & $68.4 \pm 29.9$ \\
\hline Total bilirubin, mean $\pm \mathrm{SD}, \mathrm{mg} / \mathrm{dL}$ & $0.51 \pm 0.5$ & $10.4 \pm 1.1$ \\
\hline Direct bilirubin, mean \pm SD, $\mathrm{mg} / \mathrm{dL}$ & $0.19 \pm 0.3$ & $7.4 \pm 0.5$ \\
\hline
\end{tabular}


Table 2. Comparison of Thiol Disulphide and IMA parameters of the control and obstructive jaundice groups

\begin{tabular}{|l|c|c|c|}
\hline & Control & Obstructive jaundice & $p$ \\
\hline Native Thiol $(\mu \mathrm{mol} / \mathrm{L})$ & $415.838 \pm 66.05$ & $328.16 \pm 93.50$ & $0.023^{*}$ \\
\hline Total thiol $(\mu \mathrm{mol} / \mathrm{L})$ & $469.49 \pm 61.58$ & $361.41 \pm 92.02$ & $0.025^{*}$ \\
\hline Disulphide $(\mu \mathrm{mol} / \mathrm{L})$ & $26.83 \pm 7.82$ & $16.62 \pm 9.51$ & 0.235 \\
\hline Disulphide / Native Thiol $(\%)$ & $6.69 \pm 2.28$ & $5.69 \pm 4.37$ & $0.021^{*}$ \\
\hline Disulphide / Total Thiol $(\%)$ & $5.83 \pm 1.82$ & $4.87 \pm 3.17$ & $0.014^{*}$ \\
\hline Native Thiol / Total Thiol $(\%)$ & $88.34 \pm 3.64$ & $90.26 \pm 6.35$ & $0.014^{*}$ \\
\hline IMA (ABSUs) & $70.88 \pm 4.77$ & $72.03 \pm 8.41$ & $0.030^{*}$ \\
\hline
\end{tabular}

${ }^{*} p<0.05$ indicate the statistical significance according to independent sample $t$-test
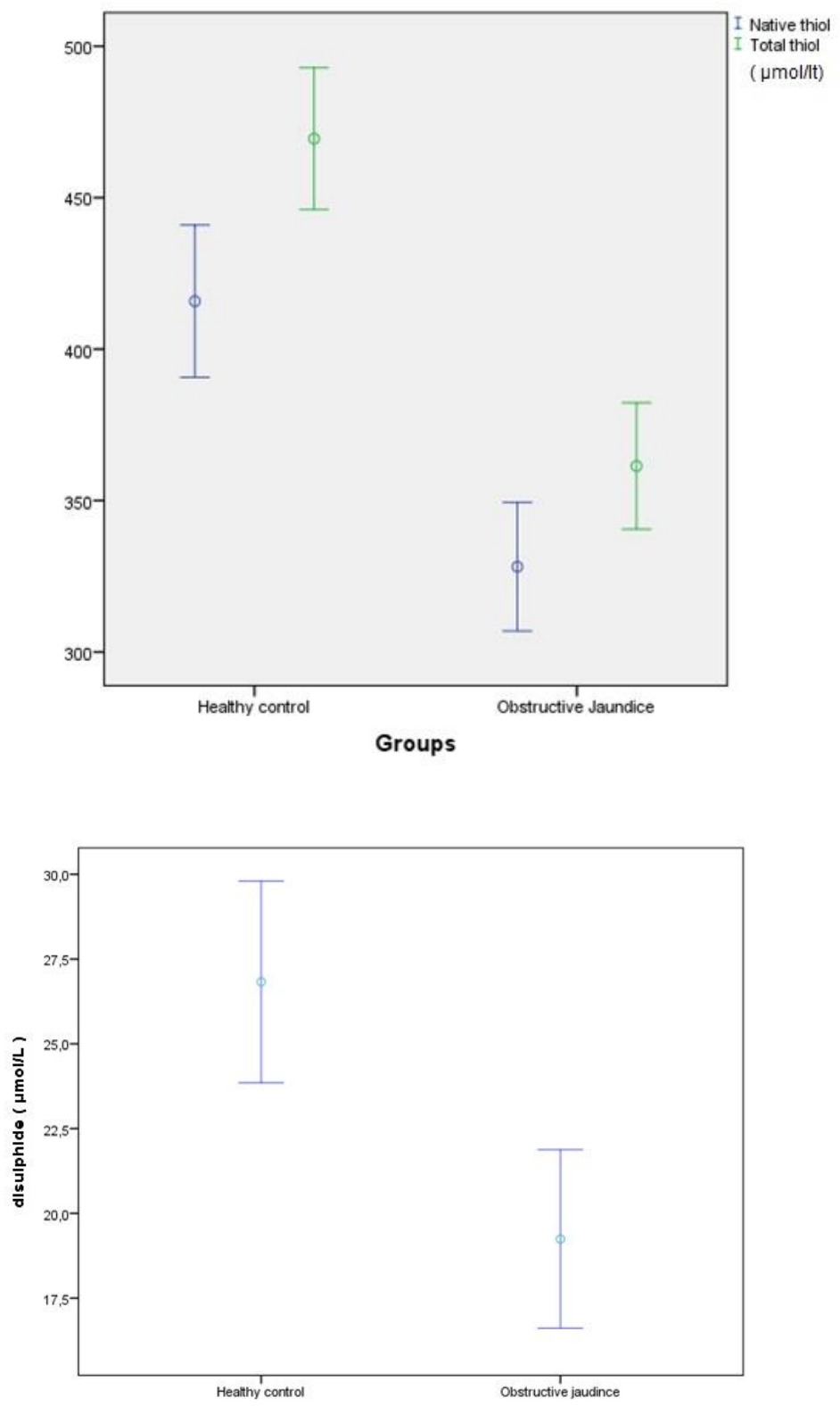

Figure 1a. The change between Total thiol /Native thiol ( $\mu \mathrm{mol} / \mathrm{lt})$ parameters according to groups
Figure 1b. The change between Disulphide ( $\mu \mathrm{mol} / \mathrm{lt}$ ) parameters according to groups 


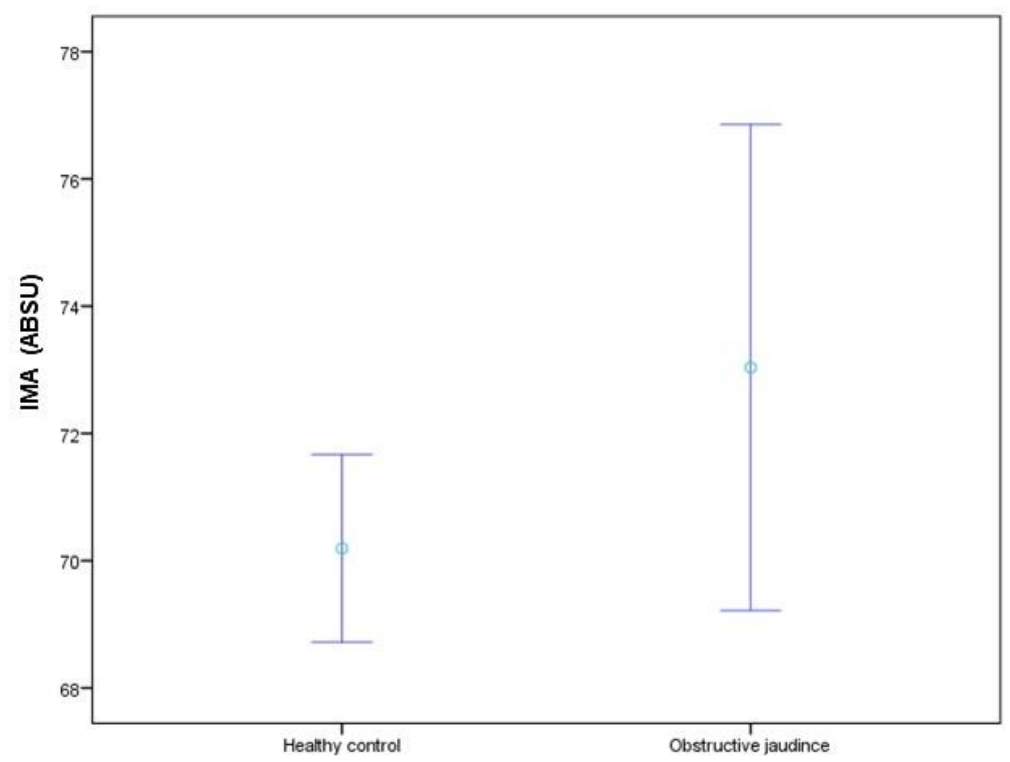

Figure 1c. The change between IMA (absu) parameters according to groups

Table 3. The correlation analysis between thiol, disulphide, IMA parameters and the other parameters

\begin{tabular}{|l|c|c|c|c|c|c|c|c|}
\hline & \multicolumn{2}{|c|}{ Native thiol } & \multicolumn{2}{c|}{ Total thiol } & \multicolumn{2}{c|}{ Disulphide } & \multicolumn{2}{c|}{ IMA } \\
\hline & $r$ & $p$ & $r$ & $p$ & $r$ & $p$ & $r$ & $p$ \\
\hline Age & -0.432 & $<0.01^{* *}$ & -0.470 & $<0.01^{* *}$ & -0.229 & $<0.01^{* *}$ & 0.222 & $<0.05^{*}$ \\
\hline $\mathrm{Na}$ & 0.365 & $<0.01^{* *}$ & 0.394 & $<0.01^{* *}$ & 0.160 & 0.103 & 0.144 & 0.144 \\
\hline ALP & -0.262 & $<0.01^{* *}$ & -0.276 & $<0.01^{* *}$ & -0.096 & 0.326 & -0.043 & 0.665 \\
\hline Glucose & -0.263 & $<0.01^{* *}$ & -0.333 & $<0.01^{* *}$ & -0.369 & $<0.01^{* *}$ & 0.006 & 0.947 \\
\hline Urea & -0.313 & $<0.01^{* *}$ & -0.322 & $<0.01^{* *}$ & -0.063 & 0.521 & 0.103 & 0.294 \\
\hline $\begin{array}{l}\text { Total } \\
\text { Bilirubin }\end{array}$ & -0.388 & $<0.01^{* *}$ & -0.377 & $<0.01^{* *}$ & 0.005 & 0.962 & -0.378 & $<0.01^{* *}$ \\
\hline $\begin{array}{l}\text { Direct } \\
\text { Bilirubin }\end{array}$ & -0.351 & $<0.01^{* *}$ & -0.337 & $<0.01^{* *}$ & 0.028 & 0.775 & -0.357 & $<0.01^{* *}$ \\
\hline Creatinine & -0.273 & $<0.01^{* *}$ & -0.302 & $<0.01^{* *}$ & -0.156 & 0.112 & -0.308 & $<0.01^{* *}$ \\
\hline
\end{tabular}

${ }^{*} p<0.05$ and ${ }^{* *} p<0.01$ indicate the statistical significance according to Pearson Correlation test

\section{Discussion}

It was shown that obstructive jaundice (OJ) impairs the anatomical and functional integrity of the intestinal barrier and results in the translocation of intestinal bacteria. A systemic inflammatory response occurs after the passage of endotoxins into the systemic circulation. It causes structural and functional damages in organs 
such as the kidney, lung and heart. 13-15 Oxidative stress is seen after the inflammatory response. Some antioxidant proteins such as thiol are used to eliminate this condition. The intestinal mucosa disruption and barrier insufficiency in obstructive jaundice is associated with increased protein oxidation, lipid peroxidation and oxidation of thiol proteins. ${ }^{16}$

Dynamic thiol / disulphide homeostasis plays a critical role in detoxification, antioxidant protection, apoptosis, signal transduction, regulation of enzymatic activity and transcription factors, and cellular signaling mechanisms. ${ }^{17,18}$ Thiols are accepted as essential antioxidant buffers because they are in constant interaction with almost all physiological oxidants. 19,20 Thiol protein groups are important antioxidants that constitute $52.9 \%$ of total serum antioxidant capacity in healthy individuals. ${ }^{21}$ Erel and Neselioglu defined a novel automatic test that determines the dynamic thiol / disulphide homeostasis. Serum total thiol and native thiol levels were measured by this method, and disulphide concentrations were calculated with these levels. ${ }^{10}$ This test shows the changes in favor of thiol or disulphide.

In our study, the ratios of disulphide / total thiol and disulphide / native thiol increased significantly in favor of disulphide. However, the levels of native thiol (-SH) and total thiol (-SH + -SS) were found low. It is significant in terms of indicator for oxidative stress in patients with obstructive jaundice. The detection of a decrease in the disulphide levels suggests that oxidation is severe because it is expected that the fragmented thiols after thiol metabolism transforms into the disulphide (-SS). Until now, different studies showing oxidative stress have been performed. Other markers were used in these studies, and the present study in which we used the thiol-disulphide markers is the first study according to our current knowledge. ${ }^{\mathbf{1 6}}$

Increased bilirubin levels after cholestasis seen in obstructive jaundice are one of the systemic inflammatory responses. This situation triggers oxidative stress. In our study, there is an inverse correlation between total / direct bilirubin levels and thiol-disulphide homeostasis. It was observed that there was a significant correlation between the increase of bilirubin level and the decreasing thiol levels with oxidative stress. The decrease in thiol levels shows oxidative stress.

Ischemia-modified albumin (IMA), protein carbonyl and superoxide dismutase are other markers for oxidative stress. ${ }^{22,23}$ IMA is an altered type of serum albumin that forms under conditions of oxidative stress, and it increases due to oxidative stress after acute ischemia. IMA returns to normal levels within hours after reperfusion. IMA is a sensitive marker in myocardial infarction, peripheral vascular diseases, chronic renal disease and diabetes mellitus. ${ }^{24-28}$ We also evaluated the significance of IMA for obstructive jaundice. We detected that the IMA has the potential to be used as a marker similar to thiol-disulphide for showing oxidative stress. 
The disruption of thiol / disulphide homeostasis in obstructive jaundice suggests that it may play a role in the pathogenesis of OJ. Supplementation with thiol compounds such as N-acetyl cysteine (NAC) may be a target for the treatment of OJ. NAC is a free radical scavenger that stimulates glutathione synthesis. There are studies showing that NAC treatment is recommended in other clinical cases. ${ }^{29,30}$ We think that antioxidant support, including NAC or glutathione, may reduce hospital stay and complication rates in patients with obstructive jaundice.

The disruption of the thiol-disulphide homeostasis plays a role in the pathogenesis of obstructive jaundice. Thiol-disulphide homeostasis may be a new biomarker of oxidative stress in obstructive jaundice

\section{Limitations}

The study population is small. Dynamic thiol-disulphide homeostasis is affected by various diseases and conditions. There may be conditions affecting oxidative stress in patients with obstructive jaundice. Does the giving of thiol sources as treatment contribute to the reduction of oxidative stress in patients with obstructive jaundice? Does it have a role in etiopathogenesis? Further studies are needed to find answers to these questions.

\section{Ethical Considerations}

The study was approved by the ethics committee of Yildirim Beyazit University Faculty of Medicine on 25.06.2021 with number 26379996/172.

\section{Conflict of Interest}

The authors declare that there is no conflict of interest. 


\section{References}

1. Greve JW, Gouma DJ, Buurman WA. Complications in obstructive jaundice: role of en dotoxins. Scand J Gastroenterol Suppl 1992;194:8-12.

2. Kuzu MA, Kale IT, Col C, et al. Obstructive jaundice promotes bacterial translocation in humans. Hepatogastroenterology 1999;46:2159-64.

3. Assimakopoulos SF, Vagianos CE, Patsoukis $\mathrm{N}$,et al. Evidence for intestinal oxidativestress in obstructive jaundice-induced gut barrier dysfunctionin rats. Acta Physiol Scand 2004;180:177-85.

4. Assimakopoulos SF, Scopa CD, Zervoudakis G, et al. Bombesin and neurotensin reduce endotoxemia, intestinal oxidative stress, and apoptosis in experimental obstructive jaundice. Ann Surg 2005;241:159-67.

5. Assimakopoulos SF, Scopa CD, Charonis A,et al. Experimental obstructive jaundice disrupts intestinal mucosal barrier by altering occludin expression: beneficial effect of bombesin and neurotensin.J Am Coll Surg 2004;198:748-57.

6. Sen CK, Packer L. Thiol homeostasis and supplements in physical exercise . Am J Clin Nutr. 2000;72:653-69.

7. Turell $\mathrm{L}, \mathrm{R}$ adi $\mathrm{R}$, Alvarez $\mathrm{B}$. The thiol pool in human plasma:the central contribution of albumin to redox processes . FreeRadic Biol Med. 2013;65:244-53.

8. Biswas S , Chida A S , Rahman I . Redox modifications of protein - thiols: emerging roles in cell signaling . Biochem Pharmacol. 2006;71:551-64.

9. Circu M L, Aw TY . Reactive oxygen species, cellular redox systems, and apoptosis. Free Radic Biol Med. 2010;48:749-62.

10. Erel O, Neselioglu S . A novel and automated assay for thiol/disulphide homeostasis . Clin Biochem. 2014;47:326-32.

11. Ellman G, Lysko H. A precise method for the determination of whole blood and plasma sulfhydryl groups. Analytical biochemistry. 1979;93:98-102.

12. Bar-Or D, Lau E, Winkler JV. A novel assay for cobalt-albumin binding and its potential as a marker for myocardial ischemia-a preliminary report. The Journal of Emergency Medicine. 2000;19(4):3115 (doi:10.1016/s0736-4679(00)00255-9).

13. Clements WD, Erwin P, McCaigue MD, Halliday I, Barclay GR, Rowlands BJ. Conclusive evidence of endotoxaemia in biliary obstruction. Gut. 1998;42(2):293-9 (doi:10.1136/gut.42.2.293).

14. Deitch EA, Sittig K,Li M, Berg R, et al. Obstructive jaundice promotes bacterial translocation from the gut. Am J Surg 1990;159:79-84.

15. Deitch EA. Multiple organ failure. Pathophysiology and potential future therapy. Ann Surg 1992;216:117-34. 
16. Assimakopoulos SF, Thomopoulos KC, Patsoukis N,et al. Evidence for intestinal oxidative stress in patients with obstructive jaundice. Eur J Clin Invest. 2006 Mar;36(3):181-7.

17. Biswas S , Chida A S , Rahman I . Redox modifications of protein - thiols: emerging roles in cell signaling. Biochem Pharmacol. 2006;71:551-64.

18. Circu M L, Aw TY . Reactive oxygen species, cellular redox systems, and apoptosis. Free Radic Biol Med. 2010;48:749-62.

19. Ergin M, Cendek BD, Neselioglu S,et al. Dynamic thiol-disulfide homeostasis in hyperemesis gravidarum. J Perinatol2015;35:789-92.

20. Otal Y, Demircan S, Sener A, et al. Acute Renal Failure and Thiol-Disulfide Homeostasis. Journal of Nephrology \& Therapeutics. 2018;08(03) (doi:10.4172/2161-0959.1000312).

21. Erel O. A novel automated direct measurement method for total antioxidant capacity using a new generation, more stable ABTS radical cation. Clin Biochem 2004;37:277-85.

22. Winterbourn CC, Bonham MJ, Buss H, et al. Elevated protein carbonyls as plasma markers of oxidative stress in acute pancreatitis. Pancreatology 2003;3:375-82.

23. Thareja S, Bhardwaj P, Sateesh J, et al. Variations in the levels of oxidative stress and antioxidants during early acute pancreatitis. Trop Gastroenterol 2009;30:26-31.

24. Hazini A, Cemek M, Is,lldak_I, et al. Investigation of ischemia modified albumin, oxidant and antioxidant markers in acute myocardial infarction. Postepy Kardiol Interwencyjnej. 2015;11:298303.

25. Hacker M, Hoyer HX, la Foug_ere C, et al. Effects of peripheral vascular intervention on ischemiamodified albumin. Coron Artery Dis. 2007;18:375-9.

26. Cichota LC, Moresco RN, Duarte MM, et al. Evaluation of ischemia-modified albumin in anemia associated to chronic kidney disease. J Clin Lab Anal. 2008;22:1-5.

27. Borderie D, Allanore Y, Meune C, et al. High ischemia-modified albumin concentration reflects oxidative stress but not myocardial involvement in systemic sclerosis. Clin Chem. 2004;50:2190-3.

28. Chawla R, Loomba R, Guru D, et al. Ischemia modified albumin (IMA) - a marker of glycaemic control and vascular complications in type 2 diabetes mellitus. J Clin Diagn Res. 2016;10:13-6.

29. Rodrigues SD, Franca KC, Dallin FT, et al. N-acetylcysteine as a potential strategy to attenuate the oxidative stress induced by uremic serum in the vascular system. Life Sci. 2015;121:110-6 (doi:10.1016/j.lfs.2014.11.024).

30. Heller AR, Groth G, Heller SC, et al. N-Acetylcysteine reduces respiratory burst but augments neutrophil phagocytosis in intensive care unit patients. 2001;29(2):272-6. 